BIOFARM

Jurnal Ilmiah Pertanian

ISSN Print: 0216-5430; ISSN Online: 2301-6442

Vol. 16, No. 1, April 2020

\title{
Pengaruh Konsentrasi Asam Salisilat dan Jenis Kemasan Terhadap Daya Simpan Buah Pisang Raja Bulu (Musa paradisiaca (L) var. Sapientum)
}

\author{
The Effect Of Salicylic Acid Concentration And Packages For The Storability \\ Of Raja Bulu Banana (Musa paradisiaca (L) var. Sapientum)
}

\author{
Feri Arya Arisanta ${ }^{1 *}$ dan Ari Handriatni ${ }^{1}$, \\ ${ }^{1}$ Program Studi Agroteknologi, Fakultas Pertanian, Universitas Pekalongan \\ *Korespondensi Penulis: feriaryaarisanta0207@gmail.com
}

\begin{abstract}
ABSTRAK
Penelitian ini bertujuan untuk mengetahui pengaruh konsentrasi asam salisilat dan jenis kemasan terhadap daya simpan buah pisang raja bulu. Penelitian ini dilakukan di laboratorium Fakultas Pertanian, Universitas Pekalongan. Penelitian ini disusun dalam Rancangan Acak Lengkap (RAL) yang terdiri atas 2 faktorial dengan ulangan 3 kali. Data dianalisis dengan uji $\mathrm{F}$ dan jika terdapat beda nyata dilanjutkan dengan uji BNT taraf $5 \%$. Faktor pertama konsentrasi asam salisilat meliputi tanpa asam salisilat, $1 \mathrm{~g} / \mathrm{l}$ asam salisilat, $2 \mathrm{~g} / \mathrm{l}$ asam salisilat, dan $3 \mathrm{~g} / \mathrm{l}$ salisilat, faktor kedua jenis kemasan meliputi plastik polietilen (PE), plastik polipropilen (PP), dan kardus karton. Variabel yang diamati meliputi kekekerasan, luas spot hitam, tingkat kerusakan, umur simpan, berat susut, kadar air pisang, laju respirasi, asam tertirasi total, kandungan vitamin C, padatan terlarut total. Hasil penelitian menunjukkan bahwa perlakuan konsentrasi asam salisilat berbeda sangat nyata terhadap semua variabel yang diamati. Perlakuan jenis kemasan berbeda sangat nyata terhadap semua variabel yang diamati kecuali tidak berbeda nyata pada variable kekerasan, kadar air dan asam tertitrasi total. Interaksi konsentrasi asam salisilat dan jenis kemasan berbeda sangat nyata pada variabel tingkat kerusakan, umur simpan dan laju respirasi, berbeda nyata pada variabel luas spot hitam. Interaksi terbaik dicapai pada konsentrasi asam salisilat $2 \mathrm{~g} / \mathrm{l}$ dan jenis kemasan plastik polietilen (PE). Perlakuan konsentrasi asam salisilat berpengaruh meningkatkan lama umur simpan buah pisang raja bulu menjadi 4-6 hari lebih lama dibandingkan tanpa kosentrasi asam salisilat.
\end{abstract}

Kata kunci: pisang raja bulu, asam salisilat, jenis kemasan, daya simpan buah.

\begin{abstract}
The purpose of this study was to know the effect of salicylic acid contentration and packaging for the storability of raja bulu banana. This study was conducted in the laboratory of the Faculty of Agriculture University of Pekalongan. The experiment was analyzed as completely randomized design (CRD) consisting 2 factorial, and replicated three times. The data were analyzed by $F$ test and continued with Least Significance Different (LSD) level $5 \%$ if the result was significant difference. The first factor is ethylene adsorber ratio include no salicylic acid contentration, $1 \mathrm{~g} / \mathrm{l}$ of salicylic acid, $2 \mathrm{~g} / \mathrm{l}$ of salicylic acid, and 3 $\mathrm{g} / \mathrm{l}$ of salicylc acid, second factor is packages include polyethylene package (PE), polypropilen package (PP), and carton package. Variables analyzed were texture, black spot wide, damage rate, storage time, weight loss, moisture contains, respiration rate, total titrated acids, vitamin $c$, and total dissolved solids. The results showed that ethylene adsorber ratio treatments had highly significant difference on all variables. Packages treatment had highly significant difference on all variables but not significant different on texture, moisture contains, and total titrated acids. The interactions of salicylic acid concentration and packages had highly significant difference in damage rate, storgae time and respiration rate, but significant difference on black spot wide. Best interactions achieved at Salicylic acid concentration $2 \mathrm{~g} / \mathrm{l}$ and types of polyethylene package (PE). Salicylic acid concentration treatment increased the storabilty of raja bulu banana into 4-6 days longer than without salicylic acid concentration.
\end{abstract}

Keywords: raja bulu banana, salicylic acid, packages, fruit storability.

\section{PENDAHULUAN}

Pisang (Musa Paradisiaca) merupakan salah satu komoditas asli Asia Tenggara dan termasuk buah-buahan penting di kawasan Filipina, Malaysia, dan Indonesia, baik ditinjau luas lahan maupun produksinya (Sambeganarko, 2008). Buah pisang yang merupakan produk utama dari tanaman pisang dapat dimanfaatkan sebagai konsumsi buah segar dan beberapa olahan seperti keripik pisang, tepung pisang, sale pisang, dan roti pisang. Buah pisang merupakan bahan pangan yang bergizi dan mengandung 22,84\% karbohidrat, 1,09\% 
protein, $12,23 \%$ gula, dan 8,7\% vitamin C. Komponen karbohidrat pada buah pisang adalah pati pada daging buahnya dan akan diubah menjadi sukrosa, glukosa, dan fruktosa pada saat pisang matang (Bello dkk, 2000).

Indonesia merupakan salah satu sentra primer keragaman pisang. Lebih dari 200 jenis pisang terdapat di Indonesia. Tanaman pisang dapat menghasilkan 750 tandan/ha dengan berat rata-rata $30 \mathrm{~kg}$. Berdasarkan data Badan Pusat Statistik dan Direktorat Jenderal Hortikultura (2018) produksi pisang di Indonesia sebesar 7,2 juta ton/ha. Hal ini memberikan peluang untuk pemanfaatan dan komersialisasi pisang sesuai kebutuhan konsumen (Departemen Pertanian, 2005).

Buah pisang termasuk buah klimakterik yang mempunyai sifat mudah rusak. Hal tersebut akan mempengaruhi kualitas buah sebelum ke tangan konsumen. Kerusakan pisang dapat terjadi pada saat disimpan atau diangkut ke tempat jauh misalnya untuk tujuan ekspor (Cahyono, 2009). Menurut Nurhasanah (2006) penanganan pascapanen yang dilakukan pedagang masih sangat sederhana. Hal tersebut dapat meningkatkan kerusakan pada buah pisang dan mempengaruhi daya simpan pisang.

Salah satu upaya untuk mempertahankan kualitas buah pisang pada saat proses fisiologis yaitu dengan penggunaan asam salisilat. Menurut Vlot dkk (2009) selama 200 tahun asam salisilat digunakan untuk obat pada manusia. Namun dalam 20 tahun terakhir asam salisilat berperan pada bidang pertanian terutama dalam pertahanan terhadap hama penyakit tanaman. Buah pisang yang mengalami kerusakan karena hama penyakit akan meningkatkan produksi etilen dan laju respirasi. Srivastava dan Upendra (2000) menyatakan perlakuan asam salisilat mampu menghambat laju respirasi buah pisang.

Pengemasan pada produk hasil pertanian merupakan salah satu cara untuk mempertahankan kondisi hasil pertanian.
Umumnya kondisi bahan hasil pertanian akan terjaga apabila dalam keaadan dikemas (Nawangsih dan Imdad, 1999). Menurut Sutarya (1995) jenis kemasan yang digunakan pada bahan hasil pertanian mempunyai karakteristik ekonomis, bahan banyak tersedia, ringan, kuat, dapat melindungi komoditi, ada ventilasi, tidak menyerap bau, dan mudah dibuang. Umumnya jenis kemasan yang biasa digunakan yaitu peti (kayu, plastik), keranjang bambu, kardus, karung jala, dan karung plastik.

Penelitian ini dilakukan untuk mengetahui pengaruh asam salisilat sebagai bahan penghambat etilen pada buah pisang Raja Bulu pada jenis kemasan.

\section{BAHAN DAN METODE}

Percobaan telah dilaksanakan selama 2 minggu yaitu mulai tanggal 9 Desember sampai 23 Desember 2019, di Laboratorium Fakultas Pertanian, Universitas Pekalongan. Rancangan yang akan digunakan dalam percobaan ini adalah Rancangan Acak Lengkap (RAL) dengan tiga ulangan yang terdiri atas dua faktor. Faktor pertama yaitu konsentrasi asam salisilat yang terdiri atas $\mathrm{KO}$ : tanpa asam salisilat (kontrol), $\mathrm{K} 1: 1 \mathrm{~g} / \mathrm{l}, \mathrm{K} 2: 2 \mathrm{~g} / \mathrm{l}$, dan K3 : $3 \mathrm{~g} / \mathrm{l}$. Sedangkan faktor kedua jenis kemasan yang terdiri atas P1 : Plastik Polietilen (PE), P2 : Plastik Polipropilen (PP), dan P3 : Kardus Karton. Dengan demikian terdapat 12 kombinasi perlakuan, masing-masing kombinasi diulang tiga kali sehingga seluruhnya ada $(4 \times 3) \times 3=36$ satuan percobaan.

Variabel yang diamati meliputi : kekerasan, luas spot hitam, kerusakan, umur simpan, berat susut, kadar air, laju respirasi, asam tertitrasi total (ATT), vitamin $\mathrm{C}$, dan padatan terlarut total (PTT). Data yang diperoleh dianalisis dengan Uji F. Jika antara faktor yang dicoba terdapat beda nyata maka dilanjutkan dengan Uji BNT 5\%. Faktor konsentrasi asam salisilat diuji menggunakan uji regresi dan faktor jenis kemasan diuji menggunakan uji orthogonal. 
HASIL DAN PEMBAHASAN

\section{Pengaruh Konsentrasi Asam Salisilat}

Hasil penelitian menunjukan kosnentrasi asam salisilat berbeda sangat nyata terhadap semua variabel yang diamati.

Etilen merupakan hormon pada tanaman yang mempengaruhi tingkat kematangan buah selama penyimpanan. Hormon ini memicu induksi dinding sel hidrolisis enzim menyebabkan peningkatan laju respirasi, pelunakan buah dan penuaan (Wills, dkk., 1998). Asam salisilat terbentuk pada tanaman sebagai reaksi terhadap serangan patogen sehingga senyawa ini memegang peranan penting dalam ketahanan tanaman (Kessman dkk., 1994). Menurut Nurhayati dkk. (2011) penyakit pascapanen pada buah pisang adalah penyakit antraknosa yang dapat mengakibatkan kerusakan pada buah hingga $70 \%$. Hal tersebut menjadi penyebab buah mudah rusak dan daya simpan rendah.

Buah pisang yang mengalami kerusakan fisik dan terserang penyakit akan mengakibatkan produksi etilen meningkat (Kader, 1992). Srivastava dan Upendra (2000) menyatakan bahwa asam salisilat mampu menunda kematangan buah pisang melalui penghambatan biosintesis etilen. Asam salisilat menurunkan produksi etilen dengan mengurangi produksi ACS (aminocyclopropane carboxylic synthase) dan ACO (aminocyclopropane carboxylic oxidase) sebelumnya dikenal dengan enzim pembentuk etilen.

Tabel 1. Angka Rata-Rata dan Analisis Statistik Data Komponen Konsentrasi Asam Salisilat dan Jenis Kemasan Terhadap Daya Simpan Buah Pisang Raja Bulu.

\begin{tabular}{lccccc}
\hline \multicolumn{1}{c}{ Perlakuan } & Kekerasan & $\begin{array}{c}\text { Luas Spot } \\
\text { Hitam }\end{array}$ & Kerusakan & $\begin{array}{c}\text { Umur Simpan } \\
\text { Buah }\end{array}$ & Berat Susut \\
\hline Konsentrasi Asam & $\mathrm{kg} / \mathrm{s}$ & $\mathrm{cm}^{2}$ & $(\%)$ & $($ Hari $)$ & $(\mathrm{g})$ \\
Salisilat & & & & & \\
$\mathrm{K}_{0}=$ Kontrol & $1,32 \mathrm{a}$ & $23,35 \mathrm{~d}$ & $91,67 \mathrm{c}$ & $5,78 \mathrm{a}$ & $16,90 \mathrm{~d}$ \\
$\mathrm{~K}_{1}=1 \mathrm{~g} / \mathrm{L}$ & $1,51 \mathrm{~b}$ & $21,07 \mathrm{c}$ & $87,04 \mathrm{c}$ & $7,33 \mathrm{~b}$ & $14,92 \mathrm{c}$ \\
$\mathrm{K}_{2}=2 \mathrm{~g} / \mathrm{L}$ & $1,70 \mathrm{~cd}$ & $13,88 \mathrm{a}$ & $44,44 \mathrm{a}$ & $11,33 \mathrm{~d}$ & $11,61 \mathrm{a}$ \\
$\mathrm{K}_{3}=3 \mathrm{~g} / \mathrm{L}$ & $1,67 \mathrm{c}$ & $18,47 \mathrm{~b}$ & $53,70 \mathrm{~b}$ & $9,89 \mathrm{c}$ & $12,91 \mathrm{ab}$ \\
\hline Jenis Kemasan & & & & & \\
$\mathrm{P}_{1}=$ Plastik PE & 1,59 & $17,03 \mathrm{a}$ & $57,64 \mathrm{a}$ & $10,17 \mathrm{c}$ & $12,46 \mathrm{a}$ \\
$\mathrm{P}_{2}=$ Plastik PP & 1,55 & $19,55 \mathrm{~b}$ & $71,53 \mathrm{~b}$ & $8,5 \mathrm{~b}$ & $13,94 \mathrm{~b}$ \\
$\mathrm{P}_{3}=$ Kardus Karton & 1,52 & $20,99 \mathrm{c}$ & $78,47 \mathrm{c}$ & $7,08 \mathrm{a}$ & $15,84 \mathrm{c}$ \\
\hline
\end{tabular}

Keterangan:

Angka-angka dalam kolom dan perlakuan yang diikuti huruf yang sama menunjukkan tidak berbeda nyata berdasarkan Uji BNT taraf $5 \%, * *=$ berbeda sangat nyata, $*$ = berbeda nyata, $\mathrm{tn}=$ tidak berbeda nyata.

Menurut Muchtadi (1992), kekerasan buah menurun karena hemiselulosa dan protopektin terdegradasi. Protopektin menurun jumlahnya karena berubah menjadi pektin yang bersifat larut dalam air.

Pisang merupakan buah klimaterik yang akan memperlihatkan kehilangan warna hijau yang cepat saat pematangan. Klorofil pada buah akan terdegradasi selama masa penyimpanan normal, terjadi perubahan warna dari hijau saat mentah menjadi kuning merata ketika matang.
Menurut Pujimulyani (2009) perubahan warna dapat terjadi, baik oleh proses perombakan maupun proses sintesis atau keduanya. Perombakan terjadi pada klorofil sedangkan sintesis terjadi pada karatenoid. Pada proses pemasakan menguningnya buah pisang terjadi karena degradasi klorofil dan warna kuning pigmen karatenoid dan xantofil yang awalnya tertutup menjadi terbuka. Selain itu ada beberapa faktor yang dapat mempengaruhi perubahan warna buah salah satunya serangan patogen. Selama penyimpanan gejala yang disebabkan 
serangan patogen adalah terdapatnya bintik coklat tua atau hitam.

Penggunaan asam salisilat untuk buahbuahan dan sayuran dapat meningkatkan resistensi terhadap patogen dan mengendalikan pembusukan selama penyimpanan (Babalar, dkk., 2007). Umumnya peningkatan etilen akan terjadi jika buah mengalami kerusakan, salah satu penyebab kerusakan pada buah adalah penyakit pascapanen. Menurut Nurhayati dkk. (2011) penyakit pascapanen pada buah pisang adalah penyakit antraknosa yang dapat mengakibatkan kerusakan pada buah hingga $70 \%$. Hal ini sesuai dengan penelitian Srivastava dan Upendi (2000) menunjukkan asam salisilat menunda buah pisang selama penyimpanan hal tersebut terjadi karena asam salisilat menghambat biosintesis etilen sehingga dapat memperpanjang umur simpan buah.

Susut bobot buah pisang Raja Bulu disebabkan oleh hilangnya karbon selama proses respirasi. Pada proses respirasi, senyawa karbon yang terdapat dalam gula buah pisang akan mengikat dan bereaksi dengan oksigen yang akan menghasilkan senyawa sederhana yang mudah menguap yaitu karbondioksida dan uap air sehingga buah akan kehilangan bobotnya. Muchtadi (1992), mengemukakan bahwa kehilangan bobot pada buah-buahan yang disimpan terutama disebabkan oleh kehilangan air sebagai akibat dari proses penguapan dan kehilangan karbon selama proses respirasi. Kehilangan air selama penyimpanan tidak hanya menurunkan bobot tetapi juga menurunkan mutu dan menimbulkan kerusakan.

Winarno dkk. (1980) menyatakan bahwa perubahan kadar air pada buah dan sayur yang disimpan sebagian besar disebabkan oleh kehilangan air akibat transpirasi. Kadar air pada permukaan bahan juga dipengaruhi oleh kelembaban $(\mathrm{RH})$ udara di sekitarnya, yaitu bila kadar air bahan rendah, sedangkan $\mathrm{RH}$ di sekitarnya tinggi, maka akan terjadi penyerapan uap air dari udara sehingga bahan menjadi lembab atau kadar airnya menjadi lebih tinggi. Tetapi bila suhu bahan lebih rendah (dingin) dibandingkan suhu udara di sekitarnya akan terjadi kondensasi uap air udara pada permukaan bahan sehingga merupakan media yang baik bagi pertumbuhan kapang atau perkembang-biakan bakteri.

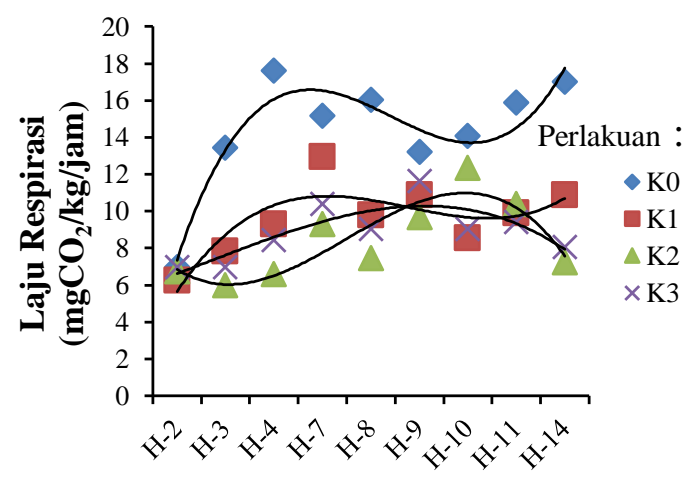
Lama Hari

Laju respirasi pisang berpola klimakterik. Pola klimakterik terjadi karena kenaikan jumlah $\mathrm{CO}_{2}$ selama penyimpanan (Gambar 1). Pisang tanpa perlakuan asam salisilat $\left(K_{0}\right)$ mengalami proses laju respirasi tercepat (puncak klimakterik) pada 4 hari setelah perlakuan. Hal ini diduga pisang tidak mengalami penghambatan pematangan sehingga laju respirasi berjalan lebih cepat. Menurut Tranggono dan Sutardi (1990) umur simpan buah akan lebih bertahan lama jika respirasi rendah, sedangkan umur simpan yang pendek ditandai dengan laju respirasi yang tinggi.

Puncak klimakterik pisang ditandai oleh adanya kematangan secara fisiologis dan morfologis. Puncak klimakterik pisang dengan perlakuan asam salisilat $1 \mathrm{~g} / \mathrm{l}\left(\mathrm{K}_{1}\right)$ terjadi pada hari ke 7 setelah perlakuan diikuti dengan konsentrasi $3 \mathrm{~g} / \mathrm{l}\left(\mathrm{K}_{3}\right)$ yang menunjukkan puncak klimakterik pada hari ke 9. Sedangkan puncak klimakterik dengan konsentrasi $2 \mathrm{~g} / \mathrm{l}$ $\left(\mathrm{K}_{2}\right)$ terjadi pada hari 10 setelah perlakuan, hal ini membuktikan bahwa perlakuan asam salisilat mampu menghambat laju respirasi buah pisang selama 6 hari dibandingkan kontrol. Berdasarkan penelitian Srivastava (2000) buah pisang dapat dihambat pematangannya selama 3 hari selama penyimpanan. Hal tersebut karena asam salisilat dapat menahan terjadi serangan patogen yang menyebabkan proses laju respirasi pisang meningkat. Timbulnya patogen pada pisang selama penyimpanan dapat mempercepat laju produksi $\mathrm{CO}_{2}$. Hasil penelitian Sholihati (2004) menyatakan 
bahwa peningkatan $\mathrm{CO}_{2}$ terjadi akibat pertumbuhan kapang dan laju respirasi yang terukur pada pisang Raja Bulu.

Selama penyimpanan buah pisang mengalami perubahan total gula dan total asam. Secara umum, saat total gula menurun maka total asam akan meningkat. Hal ini disebabkan karena saat penyimpanan terjadi pemecahan polisakarida menjadi gula sederhana. Gula tersebut digunakan untuk proses metabolisme sehingga nilai total gula mengalami penurunan. Selain itu, gula yang terbentuk dioksidasi menjadi asam piruvat dan asam organik sehingga saat total gula pada buah menurun maka total asam pada buah meningkat.

Pemasakan yang terjadi pada buah akan berdampak pada turunnya kadar asam asam organik. Penurunan asam organik diakibatkan oleh konversi asam organik menjadi gula. Proses tersebut akan dialami

Tabel 2. Angka Rata-Rata dan Analisis Statistik Data Komponen Konsentrasi Asam Salisilat dan Jenis Kemasan Terhadap Daya Simpan Buah Pisang Raja Bulu.

\begin{tabular}{lccccc}
\hline \multicolumn{1}{c}{ Perlakuan } & Kadar Air & Laju respirasi & $\begin{array}{c}\text { Asam } \\
\text { Tertitrasi } \\
\text { Total }\end{array}$ & Vitamin C & $\begin{array}{c}\text { Padatan } \\
\text { Terlarut Total }\end{array}$ \\
\hline Konsentrasi Asam & $(\%)$ & $\left(\mathrm{mgCO}_{2} / \mathrm{kg} / \mathrm{jam}\right)$ & $\mathrm{mg} / 100 \mathrm{~g}$ & $\mathrm{mg} / 100 \mathrm{~g}$ & ${ }^{0}$ Brix \\
$\begin{array}{l}\text { Salisilat } \\
\mathrm{K}_{0}=\text { Kontrol }\end{array}$ & $28,46 \mathrm{a}$ & $14,14 \mathrm{a}$ & $119,29 \mathrm{~d}$ & $8,41 \mathrm{~d}$ & $16,24 \mathrm{~d}$ \\
$\mathrm{~K}_{1}=1 \mathrm{~g} / \mathrm{L}$ & $29,35 \mathrm{~b}$ & $9,26 \mathrm{a}$ & $107,78 \mathrm{bc}$ & $7,77 \mathrm{bc}$ & $15,15 \mathrm{c}$ \\
$\mathrm{K}_{2}=2 \mathrm{~g} / \mathrm{L}$ & $30,11 \mathrm{~b}$ & $8,41 \mathrm{~b}$ & $85,51 \mathrm{a}$ & $7,15 \mathrm{a}$ & $13,52 \mathrm{a}$ \\
$\mathrm{K}_{3}=3 \mathrm{~g} / \mathrm{L}$ & $30,02 \mathrm{~b}$ & $8,86 \mathrm{c}$ & $102,02 \mathrm{~b}$ & $7,46 \mathrm{ab}$ & $14,43 \mathrm{~b}$ \\
\hline Jenis Kemasan & & & & & \\
$\mathrm{P}_{1}=$ Plastik PE & $30,47 \mathrm{c}$ & $8,97 \mathrm{a}$ & 101,20 & $7,44 \mathrm{a}$ & $14,07 \mathrm{a}$ \\
$\mathrm{P}_{2}=$ Plastik PP & $29,96 \mathrm{~b}$ & $10,30 \mathrm{~b}$ & 103,45 & $7,54 \mathrm{a}$ & $14,87 \mathrm{~b}$ \\
$\mathrm{P}_{3}=$ Kardus Karton & $28,03 \mathrm{a}$ & $11,23 \mathrm{c}$ & 106,30 & $8,12 \mathrm{~b}$ & $15,57 \mathrm{c}$ \\
\hline
\end{tabular}

Keterangan:

Angka-angka dalam kolom dan perlakuan yang diikuti huruf yang sama menunjukkan tidak berbeda nyata berdasarkan Uji BNT taraf 5\%, $* *$ = berbeda sangat nyata, $*$ = berbeda nyata, $\mathrm{tn}=$ tidak berbeda nyata

buah terkecuali pada pisang dan nanas, dimana saat pisang mengalami pematangan hingga mencapai masak penuh maka vitamin $\mathrm{C}$ akan terus meningkat (Utami dkk., 2014).

Padatan Terlarut Total (PTT) merupakan total padatan yang banyak terkandung di dalam buah. Selama proses kematangan terjadi pemecahan polimer karbohidrat seperti pati menjadi gula. Semakin tinggi kandungan padatan terlarut maka buah tersebut semakin manis. Mattoo dkk. (1989) menyatakan bahwa rasa manis pada buah disebabkan adanya peningkatan jumlah gula-gula sederhana dan berkurangnya senyawa fenolik serta kenaikan zat-zat atsiri yang memberi aroma khas pada buah. Gula merupakan komponen yang penting untuk mendapatkan rasa buah yang dapat diterima oleh konsumen melalui keseimbangan antara rasa manis dan asam.

\section{Pengaruh macam jenis kemasan}

Hasil penelitian menunjukkan bahwa perlakuan jenis kemasan berbeda sangat nyata terhadap semua variabel yang diamati, tidak berbeda nyata pada variabel kekerasan, kadar air dan asam tertitrasi total (ATT). Pisang dengan kemasan plastik polietilen (PE) mendominasi nilai tertinggi untuk beberapa variabel dari sekian banyak jumlah variabel yang diamati.

Menurut Hall dkk. (1986) plastik polietilen memiliki bahan yang kuat, kedap air, tahan terhadap zat-zat kimia, dan murah. Udara dalam kemasan menjadi udara dengan kandungan $\mathrm{O}_{2}$ rendah dan $\mathrm{CO}_{2}$ yang meningkat. Ulrich dkk. (1986) dalam Farahdiba (2016) mengungkapkan konsentrasi $\mathrm{O}_{2}$ yang rendah dapat menurunkan laju respirasi dan oksidasi substrat, menunda perombakan klorofil, 
menyebabkan produksi etilen rendah, serta menunda pematangan sehingga umur komoditi menjadi lebih panjang.

Perbandingan antara penyimpanan menggunakan plastik PE, PP dan kardus karton menunjukkan bahwa perbedaan permeabilitas antara 3 jenis kemasan ini berpengaruh sangat nyata pada komposisi akhir udara di dalam ruang penyimpanan. Hal ini juga sesuai dengan pernyataan dari Rahayu (2004), yang menyatakan permeabilitas gas PE lebih tinggi daripada PP, artinya plastik $P E$ akan melewatkan gas lebih banyak daripada PP pada ketebalan yang sama. Pengaruh ketebalan plastik terhadap perubahan konsentrasi $\mathrm{O}_{2}$ dan $\mathrm{CO}_{2}$ berhubungan dengan permeabilitas (daya tahan) terhadap $\mathrm{O}_{2}$ dan $\mathrm{H}_{2} \mathrm{O}$. Konsentrasi $\mathrm{CO}_{2}$ tinggi dan $\mathrm{O}_{2}$ yang rendah di dalam kemasan memberikan pengaruh yaitu menghambat respirasi, sehingga laju proses perombakan karbohidrat seperti gula menjadi senyawa yang mudah menguap seperti $\mathrm{CO}_{2}$ dan $\mathrm{H}_{2} \mathrm{O}$ yang akan berdampak pada hilangnya berat pada produk dapat dihambat.

Winarno (1993) menyatakan bahwa perbedaan kadar air bahan yang dikemas disebabkan oleh permeabilitas berbeda-beda dari bahan kemasan. Besarnya permeabilitas bahan pengemas terhadap air sangat berpengaruh terhadap laju kehilangan air dimana pengemas polietilen (PE) mempunyai permeabilitas terhadap uap air terkecil pada suhu $25^{\circ} \mathrm{C}$ dibandingkan bahan pengemas lain (Rahayu, 2004), sehingga dapat menghambat laju kehilangan air. Secara umum perlakuan pengemasan berpengaruh terhadap permeabilitas $\mathrm{O}_{2}$ dan $\mathrm{H}_{2} \mathrm{O}$ yang berhubungan dengan terjadinya penurunan kadar air dan berpengaruh pada perubahan susut bobot.

Buah pisang Raja Bulu sebagai buah klimakterik cenderung mengeluarkan etilen dalam proses respirasi dan pematangannya. Peningkatan produksi karbon dioksida pada penyimpanan buah pisang dipacu oleh suhu penyimpanan dan jenis kemasan. Respirasi yang cepat ada hubunganya dengan kandungan etilen dalam kemasan, pada kandungan etilen yang tinggi dapat mempercepat kegiatan respirasi dan pematangan (Harris dkk.,1997). Kemasan polietilen (PE) memberikan produksi $\mathrm{CO}_{2}$ yang rendah dibanding dengan kemasan polipropilen (PP) dan kardus karton. Hal ini karena kemasan polietilen memiliki permeabilitas $\mathrm{CO}_{2}$ lebih besar daripada $\mathrm{O}_{2}$. Permeabilitas $\mathrm{CO}_{2}$ yang lebih besar akan menyebabkan akumulasi $\mathrm{CO}_{2}$ menjadi lebih tinggi dan gas $\mathrm{O}_{2}$ juga lebih rendah dalam ruang kemasan. Pada kondisi $\mathrm{O}_{2}$ yang rendah dalam ruang kemasan akan memperlambat laju respirasi sehingga masa simpan lebih lama. Rendahnya $\mathrm{O}_{2}$ dan tingginya kadar $\mathrm{CO}_{2}$ akan memperlambat respirasi, pematangan buah, menurunkan laju produksi etilen, memperlambat pembusukan dan menekan perubahan yang berhubungan dengan pematangan (Kader, 1992).

\section{Pengaruh interaksi konsentrasi asam salisilat dan jenis kemasan}

Hasil penelitian menunjukkan adanya interaksi yang berbeda sangat nyata antara konsentrasi asam salisilat dan jenis kemasan pada variabel kerusakan, umur simpan dan laju respirasi berbeda nyata pada variabel luas spot hitam. Interaksi terbaik dicapai pada konsentrasi asam salisilat $2 \mathrm{~g} / \mathrm{l}\left(\mathrm{K}_{3}\right)$ dan jenis kemasan plastik polietilen $\left(P_{1}\right)$.

Interaksi terjadi apabila antara perlakuan konsentrasi asam salisilat dan jenis kemasan saling memberikan pengaruh. Seperti dikemukakan oleh Gomez dan Gomez (1995), bahwa dua faktor dikatakan berinteraksi apabila pengaruh suatu faktor perlakuan berubah pada saat perubahan taraf faktor perlakuan lainnya. Menurut hasil penelitian, interaksi terbaik terjadi pada perlakuan konsentrasi asam salisilat dan jenis kemasan plastik polietilen. Asam salisilat merupakan senyawa yang berperan dalam ketahanan hama penyakit tanaman. Hasil Penelitian membuktikan bahwa asam salisilat dapat menahan pertumbuhan mikroorganisme pada buah pisang Raja Bulu selama penyimpanan. Umumnya buah klimakterik akan mengalami kerusakan apabila buah terserang hama penyakit hal tersebut akan mengakibatkan produksi etilen meningkat dan laju respirasi buah akan cepat. 
Tabel 3. Angka Rata-Rata Interaksi Antara Asam Salisilat dan Jenis Kemasan Terhadap Luas Spot Hitam, Kerusakan dan Umur Simpan.

\begin{tabular}{ccccc}
\hline Perlakuan & $\begin{array}{c}\text { Luas Spot } \\
\text { Hitam } \\
\left(\mathrm{cm}^{2}\right)\end{array}$ & Kerusakan & $\begin{array}{c}\text { Umur Simpan Buah } \\
(\%)\end{array}$ & $\begin{array}{c}\text { Laju Respirasi } \\
\left(\mathrm{mgCO}_{2} / \mathrm{kg} / \mathrm{jam}\right)\end{array}$ \\
\hline K0P1 & $20,99 \mathrm{~g}$ & $91,67 \mathrm{i}$ & $6,33 \mathrm{c}$ & \\
K0P2 & $23,88 \mathrm{i}$ & $91,67 \mathrm{i}$ & $5,67 \mathrm{~b}$ & $11,74 \mathrm{~h}$ \\
K0P3 & $25,17 \mathrm{j}$ & $91,67 \mathrm{i}$ & $5,33 \mathrm{a}$ & $14,38 \mathrm{i}$ \\
K1P1 & $19,38 \mathrm{f}$ & $80,56 \mathrm{~g}$ & $8,67 \mathrm{f}$ & $16,30 \mathrm{j}$ \\
K1P2 & $21,07 \mathrm{~g}$ & $88,89 \mathrm{~h}$ & $7,00 \mathrm{~d}$ & $8,35 \mathrm{c}$ \\
K1P3 & $22,76 \mathrm{~h}$ & $91,67 \mathrm{i}$ & $6,33 \mathrm{c}$ & $9,45 \mathrm{e}$ \\
K2P1 & $11,15 \mathrm{a}$ & $25,00 \mathrm{a}$ & $13,33 \mathrm{j}$ & $9,98 \mathrm{~g}$ \\
K2P2 & $14,50 \mathrm{~b}$ & $52,78 \mathrm{c}$ & $11,67 \mathrm{~h}$ & $7,78 \mathrm{a}$ \\
K2P3 & $16,00 \mathrm{c}$ & $55,56 \mathrm{e}$ & $9,00 \mathrm{~g}$ & $8,48 \mathrm{c}$ \\
K3P1 & $16,61 \mathrm{~d}$ & $33,33 \mathrm{~b}$ & $12,33 \mathrm{i}$ & $8,96 \mathrm{~d}$ \\
K3P2 & $18,75 \mathrm{e}$ & $52,78 \mathrm{~d}$ & $9,67 \mathrm{~g}$ & $8,03 \mathrm{ab}$ \\
K3P3 & $19,48 \mathrm{f}$ & $75,00 \mathrm{f}$ & $7,67 \mathrm{e}$ & $8,88 \mathrm{~cd}$ \\
\hline
\end{tabular}

Keterangan: Angka-angka dalam kolom dan perlakuan yang diikuti huruf yang sama menunjukkan tidak berbeda nyata berdasarkan Uji BNT taraf $5 \%, * *=$ berbeda sangat nyata, $*=$ berbeda nyata, $\mathrm{tn}=$ tidak berbeda nyata.

Menurut Rochman (2007) plastik film memberikan perlindungan terhadap kehilangan air pada buah, sehingga buah yang dikemas masih terlihat segar. Proses pengemasan akan mengakibatkan modifikasi atmosfer dimana konsentrasi $\mathrm{CO}_{2}$ akan lebih tinggi daripada $\mathrm{O}_{2}$. Prinsip respirasi pada produk setelah dipanen adalah produksi $\mathrm{CO}_{2}$, $\mathrm{H}_{2} \mathrm{O}$ dan energi dengan mengambil $\mathrm{O}_{2}$ dari lingkungan. Modifikasi atmosfir menurut Kader (1992) akan memperlambat proses pematangan buah, menurunkan laju produksi etilen, memperlambat pembusukan, dan menekan berbagai perubahan yang berhubungan dengan pematangan. Permeabilitas yang rendah dan disertai dengan fungsi pengemasan dalam menurunkan jumlah $\mathrm{O}_{2}$ selama proses pengemasan selain berpengaruh terhadap penghambatan respirasi juga berpengaruh terhadap produksi etilen endogen. Etilen endogen merupakan hormon pemicu pematangan yang dihasilkan buah itu sendiri. Burg (2004) menjelaskan bahwa $\mathrm{O}_{2}$ berperan dalam mengaktifkan kinerja dari etilen, sehingga dengan permeabilitas $\mathrm{O}_{2}$ yang rendah pada plastik PE akan menghambat pengaktifan etilen sehingga mengurangi pengaruh etilen dalam mempercepat pematangan. Pengemasan ini akan meningkatkan jumlah $\mathrm{CO}_{2}$, dimana $\mathrm{CO}_{2}$ itu sendiri bersifat antagonis terhadap produksi etilen endogen. Gas $\mathrm{CO}_{2}$ yang tinggi merupakan penghambat kerja etilen sebab gas ini menunda kematangan buah dengan menggantikan etilen dari tempat reseptornya (Burg, 2004). Menurut Pantastico (1993) konsentrasi $\mathrm{O}_{2}$ yang rendah dapat mempunyai pengaruh terhadap laju respirasi dan oksidasi subtrat menurun, pematangan tertunda dan sebagai akibatnya umur komoditi menjadi lebih panjang, perombakan klorofil tertunda dan produksi etilen rendah.

\section{SIMPULAN}

Berdasarkan hasil penelitian dan pembahasan dapat diambil simpulan sebagai berikut.

1. Perlakuan konsentrasi asam salisilat berbeda sangat nyata terhadap semua variabel yang diamati. Konsentrasi optimum asam salisilat $2 \mathrm{~g} / \mathrm{l}$ dapat digunakan untuk meningkatkan umur simpan dan mempertahankan mutu fisik buah pisang Raja Bulu.

2. Perlakuan macam jenis kemasan berbeda sangat nyata terhadap semua variabel yang diamati. Kemasan terbaik plastik 
polietilen (PE) dapat digunakan untuk meningkatkan umur simpan dan mempertahankan mutu fisik buah pisang Raja Bulu.

3. Interaksi berbeda sangat nyata antara konsentrasi asam salisilat dan jenis kemasan pada variabel laju respirasi, kerusakan, dan umur simpan, berbeda nyata pada variabel luas spot hitam pisang Raja Bulu. Interaksi terbaik dicapai pada konsentrasi $2 \mathrm{~g} / \mathrm{l}\left(\mathrm{K}_{2}\right)$ dan jenis kemasan plastik polietilen $\left(P_{1}\right)$.

\section{DAFTAR PUSTAKA}

Badan Pusat Statistik. 2018. Produksi Tanaman Hortikultura. http://bps.go.id (diakses 30 Oktober 2018).

Bello-Pérez, L.A. A. De Francisco, E. AgamaAcevedo, F. Gutierrez-Meraz, F. J.L. García-Suarez. 2005. Morphological And Molecular Studies of Banana Starch. Sage Publications: Doi: 10: 1177.

Cahyono, Bambang. 2009. Pisang Usaha Tani Dan Pasca Panen. Kanisius. Yogyakarta.

Departemen Pertanian. 2005. Prospek Dan Arah Pengembangan Agribisnis Pisang. Jakarta: Badan Penelitian Dan Pengembangan Pertanian Departemen Pertanian.

Faradilla dan Purwantoro, A. 2012. Induksi Ketahanan Pisang Terhadap Fusarium Oxysporum f. Sp Cubense (Foc) Dengan Asam Salisilat dan Asam Fusarat Dalam Kultur Jaringan.Universitas Gadjah Mada.

Farahdiba, A. D., 2018. Pengaruh Bahan Penyerap Etilen dan Jenis Kemasan Terhadap Umur Simpan Buah Pisang Ambon Hijau (Musa paradisiaca var. Sapientum (L.) Kunt.). Skripsi. Fakultas Pertanian. Universitas Pekalongan. Pekalongan.

Fessenden, R. J. and Fessenden, J. S. 1986. Kimia Organik Edisi ketiga Jilid kedua. Erlangga. Jakarta. Alih Bahasa Pudjaatmaka, A. H. Terjemahan dari : Organic Chemistry, Third Edition.

Kader, A.A. 1992. Postharvest Biology And Technolgy : An Overview. P.15-20. Dalam. Kader, A.A. (Ed).
Postharvest Technology For Horticultural Crops. (Second Edition). Publ. 3311. University Of California Barkeley.

Mattoo AK, Murata T, Pantastico Er B. Chachin K, Ogata, and Phan CT. 1989. Perubahan-perubahan kimiawi selama kematangan dan penuaan. In: Pantastico Er B (Ed.). Fisiologi Pascapanen Penanganan dan Pemanfaatan Buah-buahan dan Sayur-sayuran Tropika dan Subtropika. Cetakan kedua. Yogyakarta (ID)

Muchtadi D. 1992. Fisiologi Pasca Panen Sayuran dan Buah-buahan. Pusat Antar Universitas Pangan dan Gizi. Institut Pertanian Bogor. Bogor.

Muchtadi TR, Sugiyono, Ayustaningwarno F. 2010. Ilmu Pengetahuan Bahan Pangan. Bandung: Alfabeta.

Mudjisihono R., D Hindiarto., Z dan Noor. 2001. Pengaruh Kemasan Plastik Terhadap Mutu Sawit Kering Selama Penyimpanan. Jurnal Penelitian Pertanian.

Nawangsih, A. A., dan Imdad, H. P. 1999. Menyimpan Bahan Pangan. Penyebar Swadaya. Jakarta.

Nurhasanah. 2006. Survei Kondisi Dan Daya Simpan Pisang (Musa Paradisiaca L) Kultivar Raja Bulu Di Pasar Induk Kramat Jati Dan Sekitar Bogor. Bogor: Skripsi. Departemen Agronomi Dan Hortikultura. Fakultas Pertanian, Ipb. Bogor.

Nurhayati., Umayah, A., Berdnand, H. 2011. Efek Lama Perendaman dan Konsentrasi Pelarut Daun Sirih Terhadap Perkembangan Penyakit Antraknosa Pada Buah Pisang. J Dharmapala. 4(1). Universitas Sriwijaya. Palembang.

Pantastico, E.R.B. 1993.Fisiologi Pasca Panen, Penanganan Dan Pemanfaatan Buah-Buahan Dan Sayuran Tripika Da Sub Tropika. Gadjah Mada University Press, Yogyakarta.

Prabawati, S., Suyanti dan Setyabudi, D. A. 2009. Teknologi Pasca Panen dan Teknik Pengolahan Buah Pisang. Badan Penelitian dan Pengembangan Pertanian. 
Pujimulyani, D. 2009. Teknologi Pengelolahan Sayur-Sayuran Dan Buah-Buahan. Graha Ilmu. Yogyakarta.

Raskin, I. 1992. Role of Salicylic Acid in Plants. Ann. Rev. Plant Physiol. 43:439-463.

Satuhu, S., Supriyadi, A. Budidaya Pengolahan dan Prospek Pasar Pisang. Penebar Swadaya. Yogyakarta

Satyan, Shashirekha, Scott KJ, Graham D. 1992. Storage Of Banana Bunches In Sealed Polyethylene Bags. Journal of Horticultural Science 67(2):283-287.

Srivastava, M. K., Dwivedi, U. N. 2000. Delayed Ripening Of Banana Fruit By Salicylic Acid. Plant Science: 158:8796.

Sutarya, R., G., Gruben, H., Sutarno. 1995. Pedoman Bertanam Sayuran Segar. Ugm Press: Yogyakarta.

Suyanti, Dan Ahmad Supriyadi. 2008. Pisang Budidaya Pengolahan Dan Prospek Pasar. Penebar Swadaya, Jakarta.

Swara, Eko Prames. 2011. Perlakuan Pendahuluan Buah Pisang Cavendish (Musa Cavendishii) Untuk Penyimpanan. Skripsi. Departemen Teknologi Industri Pertanian Fakultas Teknologi Pertanian Institut Pertanian Bogor,. Bogor.
Thomson JF. 1985. Psychrometric and perishable commodities. Postharvest Technologi of Holticultural Crop. Devision of Agriculture and Naural esources. University of Caifornia.

Utama, S. M. I., Komang A., Nocianitri, Fitri W. T.2006. Mempelajari Pengaruh Ketebalan Plastik Film Polietilen Densitas Rendah Sebagai Bahan Kemasan Buah Manggis Terhadap Modifikasi Gas Oksigen Dan Karbondioksida. Universitas Udayana. Bali.

Vlot, A. C., Dempsey, D. A., Klessig, D. F. 2009. Salicylic acid, a multifaceted hormone to combat disease. Ann. Rev: Phytopathol, 47:177-206.

Wills, R.H.H., T.H.Kee, D.Graham Wb. Mc Glasson, And E.G. Hall. 1981. Postharvest: An Introduction To The Physiology And Handling Of Fruit And Vegetables. University Press Limited. New Sout Wales, Australia

Winarno, F.G. Dan S. Laksmi. (1984). Pigmen Dalam Pengolahan Pangan. Dept. Thp. Fatemeta Ipb 